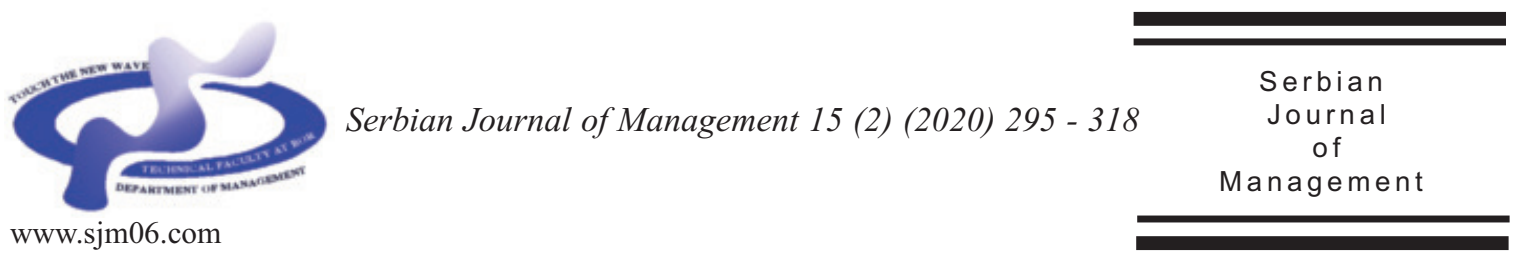

\title{
PORTFOLIO PERFORMANCE EVALUATION OF MUTUAL FUNDS IN THE REPUBLIC OF SERBIA
}

\author{
Miljan Lekovića ${ }^{\text {** }}$, Milena Jakšićcband Dragana Gnjatovića

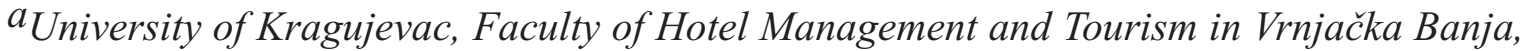 \\ Vojvođanska 5a, 36210 Vrnjačka Banja, Serbia

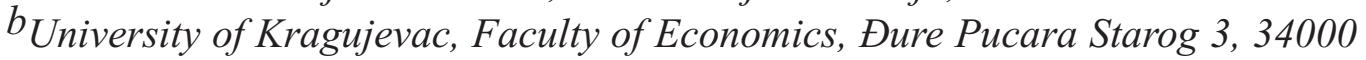 \\ Kragujevac, Serbia
}

(Received 29 March 2019; accepted 03 March 2020)

\begin{abstract}
The paper evaluates the performance of open-end mutual funds in the Republic of Serbia in the period 2011-2015, using various modelling approaches based on different models. The aim of this paper is to examine the theoretical, methodological and empirical validity of active portfolio management of mutual funds and to assess the presence of selection and timing abilities of Serbian portfolio managers. The results of the empirical research show that the active portfolio management of mutual funds in the Republic of Serbia has not been successful in terms of outperforming the market. Portfolio managers of most Serbian mutual funds lack the ability to choose profitable securities and do not have market timing ability.
\end{abstract}

Keywords: mutual funds, performance evaluation, selection ability, market timing ability

\section{INTRODUCTION}

Evaluating performance of the mutual funds' portfolios has been attracting the attention of economists for decades. The significance of this issue is reflected in the fact that by analyzing the performance of a portfolio, individual and institutional investors are informed about the effectiveness of portfolio management, while the portfolio managers are informed about the quality, advantages and disadvantages of constructed portfolio. Previous analyses aimed to determine whether the performance achieved by active portfolio management was superior to the average market performance that would be realized by simply copying the structure of some leading stock exchange index. The researchers have also been trying to determine whether realized results were achieved due to the presence (absence) of

*Corresponding author:m.lekovic@kg.ac.rs

DOI: 10.5937/sjm15-21145 
selection ability and/or timing ability of the portfolio managers of mutual funds.

In contrast to well-documented research on the performance of the mutual funds' portfolio in developed countries, literature on mutual funds and their performance evaluation is relatively scarce in the Republic of Serbia. The reason might be the fact that despite its transition to a marketoriented economic system (Veselinović et al., 2019), the Republic of Serbia has not yet managed to sufficiently develop its capital market (Pantić \& Milojević, 2019) and achieve a satisfactory level of mutual fund industry development. The absence of research on the mutual funds' portfolio performance evaluation creates the need to address this issue in order to at least partially mitigate the lack of domestic literature in this field.

In this respect, the subject matter of this paper is performance evaluation and testing of the justifiability of active portfolio management of open-end mutual funds in the Republic of Serbia. Accordingly, the aim of the research is to determine whether the mutual funds in the Republic of Serbia manage to outperform the market, in other words, whether the portfolio managers of Serbian mutual funds have selection and market timing abilities.

The obtained results should enable making relevant conclusions about the performance of Serbian mutual fund industry and the abilities of Serbian portfolio managers. Often the contradictory results of similar studies conducted in developed countries prevent the adoption of a general and final opinion on the justification of active portfolio management. Therefore, an assessment of the performance of mutual funds in the Republic of Serbia seeks to provide a contribution towards a consensus on universal superiority, equality or inferiority of performance of funds in relation to market performance.

\section{LITERATURE REVIEW}

The development of the Capital Asset Pricing Model (CAPM) and the Arbitrage Pricing Theory (APT) formed an objective basis for measuring investment performance, hence, making the favorable environment for carrying out research on this subject. The first empirical analysis of the performance of mutual funds was done by Friend, Brown, Herman and Vickers in 1962 (Friend et al., 1962). A couple of years later, William Sharpe (1966), using the annual rates of return, examined the performance of the 34 open-end mutual funds from 1954 to 1963. The performance of the tested funds was compared with market performance, more precisely with the performance of the Dow Jones Industrial Average (DJIA) market index. The author calculated the reward-tovolatility ratio, later known as the Sharpe index, for each mutual fund and compared it with a reward-to-volatility ratio for the market index. Viewed from the perspective of gross performance, 19 mutual funds managed to outperform the market, achieving larger Sharpe index than Sharpe index for the market. However, after deducting costs, the average Sharpe index for funds was 0.633 , and Sharpe index for the market was 0.677 . In other words, from the perspective of net performance, only 11 mutual funds managed to outperform the market, which clearly showed that shareholders of major number of mutual funds could not be satisfied with the achieved results. 
The creator of another standard portfolio performance measure, Michael Jensen (1968), measured the performance of 115 open-end mutual funds using annual data from 1945 to 1964 . The average value of net alpha was -0.011 , indicating that funds earned $1.1 \%$ less per year than they should in view of their level of systemic risk. On the other hand, the average gross alpha was slightly higher, but still negative, amounting to -0.004 or $-0.4 \%$ annually. Jensen concludes that funds not only failed to outperform the market on average, but also that there is little evidence that any single mutual fund managed to achieve this. This conclusion was confirmed by numerous, later conducted studies (Chang \& Lewellen, 1985; Malkiel, 1995; Bogle, 1998). Empirical research of a recent date came to similar results. Grewe and Stehle (2001) investigated the performance of open-end mutual funds that primarily invest in German equity. The analysis covered the period from 1973 to 1998 . The application of Sharpe and Jensen's index pointed to the inferiority of performance of mutual funds in relation to the performance of the selected benchmark. The results were $1.5 \%$ lower than the market on annual basis, which is significant both from statistical and economic perspective. A year later, Otten and Schweitzer (2002) made a comparison in performance of the European and American mutual fund industry in the period from January 1991 to December 1997. The survey was conducted on a sample of 506 European open-end mutual funds and 2,096 US open-end mutual funds. One of the conclusions reached by the authors suggested that the European mutual funds were showing better performance than the American ones, but neither managed to outperform the market. In the observed period, British and US mutual funds recorded a negative average alpha of $-1.04 \%$ and $-0.65 \%$, while the remaining European mutual funds achieved the alpha slightly different from zero.

The results inferior to those of the market were also identified by Davis (2001), Aragon and Ferson (2006), Harlow and Brown (2006), Abdel-Kader and Kuang (2007), Bialkowski and Otten (2011), Sajter (2011) and many others. Investigating the performance of mutual funds in the period from 1973 to 2000, Aragon and Ferson (2006) determined a negative average alpha for four of the five types of mutual funds, which undoubtedly points to the inferiority of their performance in relation to market performance. A study conducted by Harlow and Brown (2006), found that all nine investigated groups of mutual funds recorded a negative average alpha ranging from $0.32 \%$ to $-0.01 \%$ per month. In the analyzed period from 1979 to 2003, the average monthly value of the alpha index was 0.17\%. Abdel-Kader and Kuang (2007) investigated the performance of 30 open-end mutual funds in Hong Kong during the period from August 1995 to July 2005. In terms of statistical significance Jensen's alpha was found negative in all four examined categories of actively managed mutual funds and averaged -0.0159 , which clearly speaks of the lack of selection ability of their portfolio managers. Alfa coefficient was not significantly different from zero only in the case of index funds, which successfully copied the market index.

However, in the seventies of the 20th century, studies that claimed to be contrary to the above mentioned occurred. Carlson (1970) found evidence that open-end mutual funds can "beat" the market. The author partially repeated Jensen's (1968) research using annual returns for 82 open-end mutual 
funds in the period from 1948 to 1967 and reached a positive average net alpha of $0.6 \%$ per year. Jensen's (1968) research was also partially repeated by Mains (1977), who, using monthly data for the period from 1955 to 1964 , also found a positive alpha of $0.09 \%$ per year. Mains (1977) argues that Jensen used the annual returns of open-end mutual funds in his research, assuming that dividends were paid at the end of the year, while they were actually paid quarterly, indicating that Jensen ignored their reinvestment. This was also supported by Ippolito (1989), Grinblatt and Titman (1989), Goetzmann and Ibbotson (1994). Ippolito (1989) investigated the performance of mutual funds in the period from 1965 to 1984, with the conclusion that mutual funds have enough private information to exceed the costs they have created. The average alpha value in the conducted research was $0.81 \%$ per year.

Numerous recent researches also suggest that mutual fund managers succeed to "beat" the market by showing exceptional selection ability. Otten and Bams (2002) have been particularly known in the finance literature for their evaluation of the performance of European mutual funds. This evaluation was made on the sample of 506 mutual funds from five countries: France (99 funds), Germany (57 funds), Italy (37 funds), the Netherlands (9 funds) and Great Britain (304 funds). The conclusion of their research is that the average European mutual fund is able to add value, in other words to outperform relevant market indices. Performance of American industry of openend mutual funds in the period from 1975 to 2002 were examined by Kosowski et al. (2006), with the conclusion that a significant number of managers have the ability to select securities well enough to cover costs. Jagrič et al. (2007) limited their research to the period from July 1, 2000 to December 31, 2003, as well as to mutual funds established in Slovenia that have been functioning for at last three years. All nine analyzed funds achieved positive values of alpha ratio, of which even six were statistically significant. The performance of mutual funds in Slovenia was also measured by Podobnik et al. (2007). The authors analyzed the performance of fourteen Slovenian mutual funds in the period from December 31, 1999 to August 31, 2006. All observed funds achieved positive alpha indices, while $50 \%$ of these were statistically significant.

A study conducted by Chen et al. (2013) suggests that managers of open-end mutual funds in China also have selection ability. The authors examined the performance of 149 open-end mutual funds in the period from January 2004 to December 2010. A positive and statistically significant average net alpha of $0.857 \%$ per month was determined, which means that the analyzed funds earned on average $0.857 \%$ more return per month than was expected given their level of systemic risk. Wermers (2000), Chen et al. (2000), Redman et al. (2000), Baker et al. (2010) came to similar conclusions and evidence in favor of active portfolio management of mutual funds.

In addition to the aforementioned, there are numerous studies that have failed to prove either superiority or inferiority of performance of mutual funds in relation to market performance (McDonald, 1974; Swinkels \& Rzezniczak, 2009; MarkovičHribernik \& Vek, 2013). These authors, by evaluating performance of mutual funds, obtained positive values for alphas, however, these alphas were not statistically significant, which implies that the mutual fund portfolio had the same performance as the market 
portfolio. Based on all of the above, it can be concluded that in the finance literature there is no consensus on the universal superiority, equality or inferiority in the performance of mutual funds in relation to market performance.

In the literature, in addition to selection skills, special attention is paid to the ability of managers to anticipate market price trends. The ability to anticipate market fluctuations implies such a portfolio management where beta coefficient is greater than 1 when the market is rising, while it is smaller than 1 when the market is in decline. Treynor and Mazuy (1966) were the first to investigate this problem. By evaluating the performance of 57 open-end mutual funds in the period from 1953 to1962, the authors found that there is a lack of ability of mutual fund managers to anticipate market fluctuations and outperform the market. Most of academic studies conducted later came to a similar conclusion. Kon (1983) investigated the performance of 37 open-end mutual funds in the period from 1960 to 1976 , and came to the conclusion that most funds had a negative market-timing coefficient. In the case of 23 mutual funds, a statistically significant negative coefficient of market timing was determined, while the remaining 14 funds had a positive market-timing coefficient, however, these coefficients were not statistically significant. Henriksson (1984), using monthly data, examined the performance of 116 open-end mutual funds in the period from 1968 to 1980 . The results that the author obtained indicate that as much as $62 \%$ of the tested funds had a negative coefficient of market timing, while this coefficient was only statistically significant in the case of three mutual funds. General conclusion that mutual fund managers did not have the ability to forecast market trends was supported by a study conducted by Chang and Lewellen (1984) on the example of 67 open-end mutual funds.

The results of the research carried out in the 21 st century do not deviate from the above. Aragon and Ferson (2006) who investigated the performance of mutual funds in the period from 1973 to 2000, found that three of the five types of mutual funds have a negative average market-timing coefficient, which ranged from $-1.94 \%$ to $0.24 \%$ in the observed period, depending on the type of the mutual fund. Abdel-Kader and Kuang (2007) also concluded that managers of actively managed open-end mutual funds do not have the ability to forecast market movements, as confirmed by the negative market timing coefficient from the TreynorMazuy model, which, on average, amounted to $-0.3794 \%$. Škrinjarić (2013) and Chen et al. (2013) came to similar conclusions in their research. Škrinjarić (2013) examined the performance of open-end mutual funds in Croatia in the period from December 2002 to November 2011. The results obtained using the Treynor-Mazuy and Henriksson-Merton models on a sample of 10 open-end mutual funds, indicated the lack of ability of fund managers to anticipate market fluctuations and to outperform the market. The conclusion that managers of open-end mutual funds do not have the ability to anticipate market fluctuations and, on this basis, fail to outperform market conditions and construct appropriate mix in line with market trends, was confirmed in the study by Chen et al. (2013).

Nevertheless, some authors (Lee \& Rahman, 1991; Jiang et al., 2007) presented the contradictory results, which are in conflict with the above stated. Goetzmann et al. (2000) were amongst the first to point out 
that the weakness of the models that measure the ability of market timing, such as the Henriksson-Merton model, is reflected in the fact that these models are based on monthly data, while in reality decisions are made on a daily basis. Taking into account the above said, Bollen and Busse (2001) identified a significant number of portfolio managers which were able to timely adjust their portfolios to market movements. Authors claim that, if daily tests were to be conducted, the managers of open-end mutual funds would have greater capability to forecast market fluctuations than previously documented. This is confirmed by the results of the research made by Swinkels and TjongA-Tjoe (2007).

Jiang et al. (2007) found strong evidence in favor of managers' ability of market timing. The authors, using the new measures, analyzed 2,294 US mutual funds and established that their portfolio managers were able to forecast market fluctuations. A similar analysis of Korean mutual funds was also conducted by Kim and Sohn (2013), reaching the conclusion that active portfolio managers had the market timing ability.

It should be noted that some researchers have identified a worryingly negative relationship between the skill of forecasting market fluctuations and the skill of selecting appropriate securities. In a study conducted by Chang and Lewellen (1984), two mutual funds with statistically significant positive alphas simultaneously achieved a statistically significant negative markettiming coefficient. Similarly, in Henriksson's (1984) research, among 59 mutual funds with a positive alpha, 49 funds had a negative market timing coefficient, while among 57 funds with a negative alpha, 34 funds had a positive market timing coefficient.
In this respect, based on the example of mutual funds in the Republic of Serbia, the following hypotheses were tested in this paper:

Hypothesis 1: A mutual fund portfolio achieves equal or inferior performance in relation to the market portfolio;

Hypothesis 2: A mutual fund portfolio achieves superior performance in relation to the market portfolio.

Since the performance of the mutual funds' portfolios depends on the selection ability and market timing ability of portfolio managers, it is important to carry out the decomposition of initially defined hypotheses to the following hypotheses:

Hypothesis 1a: Mutual fund portfolio managers in the Republic of Serbia lack selection ability;

Hypothesis 2a: Mutual fund portfolio managers in the Republic of Serbia have the selection ability;

Hypothesis 1b: Mutual fund portfolio managers in the Republic of Serbia lack the market timing ability;

Hypothesis 2b: Mutual fund portfolio managers in the Republic of Serbia have the market timing ability.

\section{RESEARCH METHODOLOGY}

The survey assesses the performance of two thirds of open-end mutual funds in the Republic of Serbia realized in the period from January 1, 2011 to December 31, 2015. 
The emphasis is on open-end mutual funds, given their dominance, not only in the Republic of Serbia, but also in the whole world, both by the number and the value of assets managed. Risk weighted returns of mutual fund portfolios are compared with risk weighted returns of market portfolios, and portfolio performance has been measured using: Sharpe index, Treynor index, Jensen's or alpha index, M2 portfolio performance measure, information ratio and Treynor-Mazuy model.

When selecting adequate proxy for a market portfolio, the Belgrade Stock Exchange Index BELEXline gained an advantage over the BELEX15 market index, as it better describes the overall market trends on Serbian capital market. Monthly rate of return on treasury bills of the National Bank of Serbia was taken as a proxy for the risk-free rate of return.

The research used relevant data sources such as annual reports on the work of the Securities Commission of the Republic of Serbia, a database of the National Bank of Serbia and the data published by the Belgrade Stock Exchange. Data on the values of investment units of open-end mutual funds were collected from the annual reports on the work of the Securities Commission of the Republic of Serbia and on the basis of the data thus collected, the monthly rates of return of the portfolio of mutual funds were calculated:

$$
\begin{aligned}
& r_{(i, t)}=\ln \left(1+r_{i, t}^{*}\right)=\left(1+\frac{N A V_{t}-N A V_{t-1}}{N A V_{t-1}}\right) \\
& =\ln \left(\frac{N A V_{t}}{N A V_{t-1}}\right)
\end{aligned}
$$

where:

$r_{i, t}$ - logarithm rate of portfolio return of the mutual fund $i$ in the month $t$,

$r^{*} i, t$ - rate of portfolio return of the mutual fund $\mathrm{i}$ in the month $t$,

$N A V_{t}$ - net asset value per share of the fund in the month $t$,

$N A V_{t-1}-$ net asset value per share of the fund in the month $t-1$,

In - natural logarithm ${ }^{1}$.

To calculate monthly rates of return on treasury bills of the National Bank of Serbia, we used data on yearly rates of return on the securities available in the database of the National Bank of Serbia:

$r_{(f, t)}=\frac{\ln \left(1+r_{f, t}^{*}\right)}{12}$

or equivalently:

$$
r_{f, t}=\sqrt[12]{1+r_{f, t}^{*}}-1
$$

where:

$r_{f, t}-$ logarithm monthly risk-free rate of return in the month $t$,

$r_{f, t}^{*}$-risk-free rate of return in the month $t$ on annual level.

Finally, data on the movement of the BELEXline stock exchange index were taken from the Belgrade Stock Exchange website and based on the data thus collected, the monthly market rates of return were calculated:

$$
\begin{aligned}
& r_{m, t}=\ln \left(1+r_{m, t}^{*}\right)=\ln \left(1+\frac{\text { BELEXline }_{t}-\text { BELEXline }_{t-1}}{\text { BELEXline }_{t-1}}\right) \\
& =\ln \left(\frac{\text { BELEXline }_{t}}{\text { BELEXline }_{t-1}}\right)
\end{aligned}
$$

\footnotetext{
${ }^{\mathrm{T}}$ The values of all created time series in the study were transformed into a logarithmic form in order to reduce the degree of asymmetry and achieve a more regular distribution around the mean value.
} 
where:

$r_{m, t}-$ logarithm market rate of return in the month $t$,

$r_{m, t}^{*}$ - market rate of return in the month $t$,

BELEXline $_{t}$ - market value of BELEXline index in the month $t$,

BELEXline $_{t-1^{-}}$market value of BELEXline index in the month $t$ - 1

The research methodology applied is based on relevant scientific literature. The starting point of the analysis is the CAPM model from which Sharpe, Treynor and Jensen's or alpha indices were derived. The Sharpe index is calculated by dividing the incremental return of the mutual fund portfolio relative to the risk-free rate of return, with the standard deviation of portfolio return (Sharpe, 1966):

$$
S_{i}=\frac{\overline{r_{i}}-\overline{r_{f}}}{\sigma_{i}}
$$

where:

$S_{i}$ - Sharpe index of mutual fund $i$,

$\bar{r}_{i}$ - average monthly portfolio return of the mutual fund $i$,

$\overline{r_{f}}$ - average monthly risk-free rate of return,

$\sigma_{i}-$ standard deviation of portfolio return of the mutual fund $i$.

Unlike Sharpe index which is based on total portfolio risk, Treynor index is an indicator of the risk premium of the mutual fund portfolio per unit of systemic risk measured via beta coefficient (Treynor, 1965):

$$
T_{i}=\frac{\overline{r_{i}}-\overline{r_{f}}}{\beta_{i}}
$$

where:

$T_{i}$ - Treynor index of mutual fund $i$, $\beta_{i}$ - beta coefficient of the portfolio of the mutual fund $i$.

Although useful instruments for measuring the performance of mutual fund portfolio, Sharpe and Treynor indices are considered inferior performance measures compared to Jensen's index. The key reasons why Jensen's index is considered to be a superior performance measure are: 1) Jensen's index is expressed in percentages and therefore it is more suitable for interpretation, unlike Sharpe and Treynor indices that are presented as ratios; 2) Jensen's index is calculated using a linear regression equation, which provides the possibility of determining the statistical significance of the obtained results, and 3) Jensen's index implies the use of a timevarying risk-free rate of return, while in the case of Sharpe and Treynor indices constant average risk-free rate of return has been used.

In the linear regression equation on the basis of which the Jensen's or alpha index is calculated, excess return of mutual fund portfolio above the risk-free rate of return is considered as dependent variable, while excess return of market portfolio above the risk-free rate of return is considered as an independent or explanatory variable (Jensen, 1968):

$$
r_{i, t}-r_{f, t}=\alpha_{i}+\beta_{i}\left(r_{m, t}-r_{f, t}\right)+\varepsilon_{i, t}
$$

where:

$r_{i, t}-$ portfolio return of the mutual fund $\mathrm{i}$ in the month $t$,

$r_{f, t}-$ monthly risk-free rate of return in the month $t$, $\alpha_{i}$ - Jensen's or alpha index of mutual fund $i$, $\beta_{i}$ - beta coefficient of the portfolio of the mutual fund $i$, 
$r_{m, t}-$ market rate of return in the month $t$,

$\varepsilon_{i, t}$ - random error with the expected value zero in the month $t$.

Positive and statistically significant alpha index $\left(\alpha_{i}>0\right)$ from the linear regression equation indicates superior performance of mutual fund portfolio relative to average market performance and the presence of selection ability of portfolio manager of the fund. A statistically significant negative alpha index $\left(\alpha_{i}<0\right)$ testifies to the inferior performance of fund relative to market performance and the lack of selection ability of the portfolio manager of the fund. Finally, zero value of alpha index $\left(\alpha_{i}=0\right)$ as well as the lack of statistical significance of the results obtained, indicate the equal performance of mutual fund portfolio and average market performance.

In addition to the previously described measures of the portfolio performance, two modified versions of the Sharpe index are used: $M^{2}$ portfolio performance measure and information ratio. The $M^{2}$ portfolio performance measure shows to what percentage is the mutual fund portfolio performance better or worse than the average market performance, and is calculated in two ways:

- by subtracting the return of market portfolio $\left(r_{m}\right)$ from the return of adjusted portfolio $\left(r_{p^{*}}\right)$, under the condition of the equivalence of standard deviations of their returns (Modigliani \& Modigliani, 1997):

$$
M^{2}=r_{p^{*}}-r_{m}
$$

where:

$$
r_{p^{*}}=\frac{\sigma_{m}}{\sigma_{p}} r_{p}+\left(1-\frac{\sigma_{m}}{\sigma_{p}}\right) r_{f}
$$

- by multiplying the difference between Sharpe index of mutual fund $i\left(S_{i}\right)$ and Sharpe index for the market portfolio $m\left(S_{m}\right)$ with standard deviation of market return $\left(\sigma_{m}\right)$ (Francis \& Kim, 2013):

$$
M^{2}=\left(S_{i}-S_{m}\right) \sigma_{m}
$$

Second variation of the Sharpe index is the information ratio which measures the benefits of active portfolio management. It is obtained by comparing the active return with the active risk, expressed by the standard deviation of the active return (Treynor \& Black, 1973):

$$
I R=\frac{\overline{r_{p}}-\overline{r_{m}}}{\sigma_{\left(r_{p}-r_{m}\right)}}
$$

where:

$I R$ - information ratio,

$r_{p}-r_{m}-$ active return i.e. excess return of the portfolio in relation to the chosen benchmark, $\sigma_{\left(r_{p}-r_{m}\right)}$ - standard deviation of active return.

Alternative way of calculating the information ratio is to divide Jensen's index $\left(\alpha_{i}\right)$ with the standard deviation of residuals $\left(\sigma_{\varepsilon i}\right)$ as a measure of non-systemic risk:

$I R=\frac{\alpha_{i}}{\sigma_{\varepsilon i}}$

Since the realization of superior investment performance depends not only on the ability to choose the best securities, but also on the ability to anticipate market fluctuations, the research uses the TreynorMazuy model (Treynor \& Mazuy, 1966) that tests the managers' ability of market timing 
(Francis \& Kim, 2013):

$r_{i, t}-r_{f, t}=\alpha_{i}+\beta_{i}\left(r_{m, t}-r_{f, t}\right)$

$+\gamma_{i}\left(r_{m, t}-r_{f, t}\right)^{2}+\varepsilon_{i, t}$

where:

$\alpha_{i}$ - the measure of the selection ability of a portfolio manager of the mutual fund $i$, $\gamma_{i}$ - the market timing coefficient, i.e. measure of the timing ability of a portfolio manager of the mutual fund $i$.

A positive value and a statistical significance of the market-timing coefficient $\left(\gamma_{i}>0\right)$ from the square regression equation indicates the presence of the ability of portfolio managers to anticipate and respond in a timely manner to market fluctuations. A statistically significant negative markettiming coefficient $\left(\gamma_{i}<0\right)$ testifies to the wrong timing of the market, i.e. making decisions about the structure of portfolios that are not harmonized with emerging market trends. Finally, the zero value of the market-timing coefficient $\left(\gamma_{i}=0\right)$ as well as the absence of statistical significance of the obtained results, indicate the absence of the necessary market timing skills of managers.

It is important to point out that in the case of all previously described portfolio performance measures, a "rule of thumb" applies, i.e. the rule that higher value of described indicators means better performance of the mutual fund portfolio.

The inevitable tests used to verify the significance and validity of the regression are the t-test, which is used to test the hypothesis that the regression parameters are different from zero and $F$-test, which is used to test the statistical significance of the entire regression model. In terms of the $t$-test, the zero hypothesis is that the values of regression parameters are equal to zero:

$$
H_{0}: \beta_{i}=0
$$

while the alternative hypothesis points to the absence of this equality:

$H_{1}: \beta_{i} \neq 0$

The $t$-test statistics are calculated by comparing the regression parameter estimation $\left(b_{i}\right)$ with the standard error of that estimate $\left(S_{b_{i}}\right)$ :

$$
t=\frac{b_{i}}{S_{b_{i}}}
$$

If calculated, i.e., realized value of the $t$ test statistics is greater than critical value (which represents the table value of the Student's t-distribution, determined by a predefined risk of error I type, $\alpha$ ) the zero hypotheses is rejected, while an alternative hypothesis that the values of the regression parameters are different from zero is adopted.

On the other hand, the basis of the $F$-test is the determination of the coefficient $\left(R^{2}\right)$, which is calculated by squaring the correlation coefficient between the excess return of mutual fund portfolio and excess return of market portfolio. Within the $F$-test, the zero hypothesis is that the of determination coefficient is zero:

$H_{0}: R^{2}=0$

which is equivalent to the hypothesis of the zero value of the regression parameters and the absence of linear regression between the dependent and independent variables. An alternative hypothesis is that the determination coefficient is different from zero:

$H_{1}: R^{2} \neq 0$ 
which corresponds to the hypothesis of the value of the regression parameters different from zero and the presence of linear regression between the dependent and independent variables. $F$-test statistics are determined as follows (Soldić Aleksić, 2011):

$F=\frac{R^{2} / k}{\left(1-R^{2}\right)(n-k-1)}$

where:

$k$ - number of independent variables, $n$ - sample size.

If the calculated $F$-statistics is greater than the table value, the hypothesis $\mathrm{H}_{1}$ is adopted, and it is concluded that the determination coefficient is different from zero, and the regression is statistically significant.

The last step in the research is to check the fulfillment of the basic assumptions of the linear regression model: 1) the assumptions on the normality of the random error distribution, 2) the assumptions on the absence of autocorrelation of random errors, and 3 ) the assumption of homoscedasticity, i.e. equality of the residual variance. In order to check the fulfillment of the above assumptions and consequently increase the validity of obtained results, the KolmogorovSmirnov test, the Durbin-Watson test and the Glejser test are applied.

Since the sample size is greater than 50, the Kolmogorov-Smirnov test is used to verify the assumption of the normality of the distribution of the residuals. The zero hypothesis is that there is a normal distribution of the residuals, while the alternative hypothesis assumes that there is absence of normality in the distribution of residuals. Based on the realized significance level of the test, a decision is made whether to accept or reject the zero hypothesis.
The Durbin-Watson test is used to test the autocorrelation of stochastic elements. It is based on $d$ statistics (Soldić Aleksić, 2011) ${ }^{2}$ :

$d=\frac{\sum_{t=2}^{T}\left(E_{t}-E_{t-1}\right)^{2}}{\sum_{t=1}^{T} E_{t}^{2}}$

which takes values between 0 and 4 , where:

- the value of the $d$ statistics $d=2$ indicates the absence of autocorrelation of the residual,

- the value of the $d$ statistics $d=0$ indicates the presence of a perfect positive autocorrelation of the residual,

- for the value of $d$ the statistics $0<d<2$, the hypothesis on the positive autocorrelation of the residuals is tested:

- if $d$ statistics is smaller than the lower limit $d_{1}$, the zero hypothesis on the absence of a positive autocorrelation of the residual is rejected, and an alternative hypothesis about the presence of a positive autocorrelation of the residuals is accepted,

- if $d$ statistics is greater than the upper limit $d_{2}$, the zero hypothesis on the absence of a positive autocorrelation of the residuals is accepted,

- if $d$ statistics take the value between the lower and upper limits, the test is inconclusive,

- for the value of the $d$ statistics $d>2$, the hypothesis on the negative autocorrelation of the residuals is tested:

- if $d$ statistics is smaller than $4-d_{2}$, a zero hypothesis on the absence of the negative autocorrelation of the residuals is accepted,

- if $d$ statistics is greater than $4-d_{1}$, the zero hypothesis is rejected, and an alternative hypothesis of the presence of a negative autocorrelation of the residuals is accepted,

- if $\mathrm{d}$ statistics take the value between 4-

${ }^{2}$ Testing is based on comparing calculated values of $d$ statistics with table values for given number of degrees of freedom and level of significance (Soldić Aleksić, 2011). 
$d_{2}$ and $4-d_{1}$, the test is inconclusive.

To check the assumption of homoscedasticity, i.e., equality of the residual variance, the Glejser test (Glejser, 1969) is applied. Absolute residual values are regressed relative to the independent variable, whereby the absence of statistical significance of the results implies the acceptance of the zero hypothesis on the presence of homoscedasticity, i.e., the absence of heteroscedasticity problems.

Finally, it should be noted that in the research, the authors used the Statistical Package for Social Sciences - SPSS 20 as a software support for the evaluation of parameters.

\section{RESULTS OF EMPIRICAL RESEARCH}

In the analyzed five-year period, the highest average monthly rate of return $\left(r_{i}\right)$ was realized by mutual funds Raiffeisen Cash and Ilirika Cash Dinar. These funds managed to significantly exceed the average monthly rate of return of the selected index of the Belgrade Stock Exchange BELEXline. The average monthly market rate of return was also surpassed by mutual funds Raiffeisen World, Ilirika Balanced and FIMA ProActive. On the other hand, the mutual funds Ilirika Dynamic and Triumph achieved a negative average monthly rate of return in the observed period, while the mutual fund Kombank In Fond achieved a positive average monthly rate of return, but insufficient to exceed the average market rate of return (Table 1).

Nevertheless, the comparison of the average monthly return of open-end mutual funds in the Republic of Serbia with the average monthly market return does not say much about the justification of the active portfolio management of mutual funds, which is the task of the research, because it does not take into account the risk as another important dimension in the performance of funds. Therefore, it is necessary to compare the risk weighted returns of mutual funds with the risk weighted return of the BELEXline index.

The first introduced portfolio performance measure that successfully fuses

Table 1. Sharpe index, $M^{2}$ portfolio performance measure and information ratio of openend mutual funds in the Republic of Serbia, 2011-2015

\begin{tabular}{|c|c|c|c|c|c|c|}
\hline Name of Fund & $\overline{r_{i}}$ & $\overline{\boldsymbol{r}_{i}}-\overline{\boldsymbol{r}_{f}}$ & $\sigma_{i}$ & $S_{i}$ & $M^{2}$ & $I R$ \\
\hline Ilirika Cash Dinar & 0.0074 & 0.0008 & 0.0018 & 0.4444 & 0.0249 & 0.1399 \\
\hline Raiffeisen Cash & 0.0083 & 0.0017 & 0.0022 & 0.7727 & 0.0394 & 0.1596 \\
\hline FIMA ProActive & 0.0035 & -0.0031 & 0.0315 & -0.0984 & 0.0011 & 0.0739 \\
\hline Ilirika Dynamic & -0.0007 & -0.0073 & 0.0348 & -0.2098 & -0.0038 & -0.042 \\
\hline Triumph & -0.0175 & -0.0241 & 0.0689 & -0.3498 & -0.01 & -0.2343 \\
\hline Raiffeisen World & 0.0059 & -0.0007 & 0.0298 & -0.0235 & 0.0044 & 0.0973 \\
\hline Ilirika Balanced & 0.0038 & -0.0028 & 0.0257 & -0.1089 & 0.0006 & 0.0536 \\
\hline Kombank In Fond & 0.0004 & -0.0062 & 0.0297 & -0.2088 & -0.0038 & -0.0242 \\
\hline BELEXline & 0.0012 & -0.0054 & 0.044 & -0.1227 & - & - \\
\hline
\end{tabular}


the return and portfolio risk is the Sharpe index $\left(S_{i}\right)$. In the conducted research, the Sharpe index is positive in the case of mutual funds Raiffeisen Cash and Ilirika Cash Dinar, as these funds were the only ones that managed to achieve a positive risk premium. In the case of the remaining mutual funds and the stock exchange index BELEXline, Sharpe index is negative ${ }^{3}$. The highest Sharpe ratio in the observed period was realized by the mutual fund Raiffeisen Cash $\left(S_{i}=0.7727\right)$, which makes it the fund with the highest excess return per unit of total risk, while the smallest Sharpe ratio was realized by the mutual fund Triumph $\left(S_{i}=\right.$ 0.3498) (Table 1).

Much more important information than the absolute value of the Sharpe index for an individual mutual fund is a comparison of this index with the Sharpe index for the BELEXline benchmark. In the survey conducted, the Sharpe index in the case of five of the eight open-end mutual funds analyzed is larger than the Sharpe index for the benchmark. Thus, according to the Sharpe ratio, about two thirds of the tested funds achieved superior performance in relation to the market.

However, it remains unknown to what percent the performance of funds exceeds or underperforms the average market performance. The answer to this question is provided by calculating the $M^{2}$ portfolio performance measure. In the case of the mutual fund Raiffeisen Cash which has the highest Sharpe ratio, the $M^{2}$ performance measure is 0.0394, which shows that the performance of this fund is $3.94 \%$ better than the average market performance. Regarding the mutual fund Triumph, which has the smallest Sharpe ratio, the $M^{2}$ performance measure is -0.01 , indicating that the performance achieved is $1 \%$ worse than the average market performance.

Finally, calculated information ratio (IR) in Table 1 shows the amount of realized active return per unit of active risk assumed. The information ratios are positive in the case of five mutual funds whose Sharpe index is higher than the Sharpe index for the benchmark. A positive information ratio indicates that decision to actively manage the portfolio has resulted in a higher return of the portfolio compared to the average market return. In other words, the portfolio manager succeeded to "beat" the market at riskweighted basis by creating a portfolio different from the benchmark. On the other hand, the information ratio is negative in the case of three mutual funds whose Sharpe index is lower than the Sharpe index for the benchmark. Negative information ratio suggests that the decision to create a portfolio that is different from a benchmark has resulted in poorer performance than the average market performance.

Bearing in mind the fact that the Sharpe index is a reliable indicator of performance only in the case of the undiversified or poorly diversified portfolios, indicators such as Treynor $\left(T_{i}\right)$ and Jensen's or alpha index $\left(\alpha_{i}\right)$ have also been calculated (Table 2).

The fund with the highest Treynor index Ilirika Cash Dinar $\left(T_{i}=0.8\right)$ is the fund with the highest excess return above the risk-free rate of return per unit of systemic risk, while the largest negative excess return per unit of systemic risk was realized by the mutual fund Raiffeisen Cash. It is only in the case of the mutual funds Ilirika Cash Dinar and Raiffeisen World that the Traynor ratio of these funds is higher than the Treynor ratio of the BELEXline benchmark, which is equal to risk premium and amounts to $T_{i}=$ 0.0054. Thus, according to Treynor index, over two thirds of the tested funds achieved

\footnotetext{
${ }^{3}$ The interpretation of negative Sharpe index is the same as the interpretation of the positive one. In other words, the rule that the higher the index, the better the performance of the portfolio, is also applied (Sajter, 2011, 259).
} 
inferior performance in relation to the market.

Based on the above, it is concluded that in the case of the largest number of mutual funds in the Republic of Serbia, the Sharpe index points to superior and Treynor index to inferior performance of funds ${ }^{4}$. Also, Treynor index for all mutual funds, other than the Raiffeisen Cash Fund, is higher than the Sharpe index, which is explained by the presence of a high non-systemic risk caused by insufficient portfolio diversification. It should be emphasized that possible ranking of funds would differ according to Sharpe and Treynor index, which confirms the conclusion that the mutual fund portfolios in the Republic of Serbia are not sufficiently diversified.

Regardless of the indisputable usefulness of Sharpe and Treynor index, Jensen's alpha is considered a superior performance measure. In the conducted research, only the mutual funds Raiffeisen Cash and Ilirika Cash Dinar achieved positive and statistically significant value of the alpha index. The Jensen's index is 0.002 in the case of the Raiffeisen Cash fund, i.e. 0.001 in the case of the Ilirika Cash Dinar fund, which means that these funds realized $0.2 \%$ and $0.1 \%$ more return per month than expected in view of the assumed level of systemic risk. The portfolio of these funds has achieved superior performance in relation to the market portfolio, and portfolio managers have shown satisfactory selection ability.

On the other hand, the mutual fund Triumph realized the statistically significant negative value of the alpha index and inferior performance. Active portfolio management of this fund resulted in lower actual return than expected return. The Jensen's index of 0.024 shows that the Triumph mutual fund averaged $2.4 \%$ less return per month than expected, given the assumed level of systemic risk. The remaining analyzed mutual funds in the Republic of Serbia are characterized by negative alpha indexes, but without statistical significance, which points

Table 2. Sharpe, Treynor and Jensen's or alpha index of open-end mutual funds in the Republic of Serbia, 2011-2015

\begin{tabular}{|c|c|c|c|c|c|c|c|}
\hline Name of Fund & $S_{i}$ & $\beta_{i}$ & $T_{i}$ & $\alpha_{i}$ & $R^{2}$ & $F$ & Sig \\
\hline Ilirika Cash Dinar & 0.4444 & $\begin{array}{c}0.001 \\
(0.671)\end{array}$ & 0.8 & $\begin{array}{c}0.001 \\
(8.498)^{*}\end{array}$ & 0.008 & 0.451 & 0.505 \\
\hline Raiffeisen Cash & 0.7727 & $\begin{array}{c}-0.004 \\
(-1.257)\end{array}$ & -0.425 & $\begin{array}{c}0.002 \\
(12.663)^{*}\end{array}$ & 0.027 & 1.581 & 0.214 \\
\hline FIMA ProActive & -0.0984 & $\begin{array}{c}0.511 \\
(7.730)^{*}\end{array}$ & -0.0061 & $\begin{array}{l}-0.0004 \\
(-0.125)\end{array}$ & 0.507 & $59.757^{*}$ & 0.000 \\
\hline Ilirika Dynamic & -0.2098 & $\begin{array}{c}0.293 \\
(3.037) *\end{array}$ & -0.0249 & $\begin{array}{c}-0.006 \\
(-1.361)\end{array}$ & 0.137 & $9.223 *$ & 0.004 \\
\hline Triumph & -0.3498 & $\begin{array}{c}0.077 \\
(0.378)\end{array}$ & -0.313 & $\begin{array}{c}-0.024 \\
(-2.638)^{*}\end{array}$ & 0.002 & 0.143 & 0.706 \\
\hline Raiffeisen World & -0.0235 & $\begin{array}{c}0.135 \\
(1.546)\end{array}$ & -0.0052 & $\begin{array}{c}-0.00004 \\
(-0.011)\end{array}$ & 0.040 & 2.391 & 0.128 \\
\hline Ilirika Balanced & -0.1089 & $\begin{array}{c}0.069 \\
(0.917)\end{array}$ & -0.0406 & $\begin{array}{c}-0.003 \\
(-0.750)\end{array}$ & 0.014 & 0.841 & 0.363 \\
\hline Kombank In Fond & -0.2088 & $\begin{array}{c}0.456 \\
(6.835)^{*}\end{array}$ & -0.0136 & $\begin{array}{c}-0.004 \\
(-1.286)\end{array}$ & 0.446 & $46.715^{*}$ & 0.000 \\
\hline BELEXline & -0.1227 & 1.000 & -0.0054 & 0.000 & 1.000 & - & - \\
\hline
\end{tabular}

\footnotetext{
${ }^{4}$ Contradictory results are due to $a p p l y i n g$ different risk measures, i.e., the fact that Sharpe index is based on the standard deviation, while Treynor index is based on beta coefficient as a measure of risk.
} 
to the equality of performance of their portfolios and average market performance. Thus, even six of the eight mutual funds analyzed in the observed five-year period achieved equal or inferior performance compared to the market portfolio. Portfolio managers of most Serbian mutual funds simply lack the selection ability, i.e. the necessary skills to choose securities, which is the reason they fail to outperform the market. The obtained results are consistent with the conclusions reached by Jensen (1968), Chang and Lewellen (1985), Malkiel (1995), Otten and Schweitzer (2002), Aragon and Ferson (2006) and Sajter (2011).

Based on the above, it is concluded that the calculated alpha index values confirm the validity of hypothesis 1 and hypothesis $1 \mathrm{a}$ in the case of $75 \%$ of the analyzed mutual funds in the Republic of Serbia. The validity of hypothesis 2 and hypothesis $2 \mathrm{a}$ is confirmed only in the case of mutual funds Raiffeisen Cash and Ilirika Cash Dinar whose alpha indices are statistically significantly positive.

In addition to the $t$-test, which showed that the alpha index was statistically significant at the level of 0.05 in the case of mutual funds Ilirika Cash Dinar, Raiffeisen Cash and Triumph, the $F$-test based on the determination coefficient $\left(R^{2}\right)$ was applied in the study and it pointed out to the statistical significance of the entire regression model in the case of mutual funds FIMA ProActive, Ilirika Dynamic and Kombank In Fond. Determination coefficient of these funds shows that $50.7 \%$ of the change in the excess return of the portfolio of the mutual fund FIMA ProActive, $13.7 \%$ of the change in the excess return of the portfolio of the mutual fund Ilirika Dynamic and $44.6 \%$ of the change in the excess return of the portfolio of the mutual fund Kombank In Fond can be explained by the change in the excess return of the market portfolio (Table 2). In the case of the remaining mutual funds, $F$-statistics is lower than the table value, therefore the zero hypothesis that the coefficient of determination is zero is accepted. The adoption of the zero hypothesis implies the absence of a statistically significant linear regression between the excess return of the portfolio of the mutual fund and the excess return of the market portfolio. This is explained by the fact that the structure of the portfolio regarding the remaining five mutual funds is dominated by foreign securities or term deposits with banks:

- In the structure of the investment portfolio of Ilirika Cash Dinar, term deposits with banks dominate, representing $68.56 \%$ (www.ilirika.rs),

- In the structure of the investment portfolio of Ilirika Balanced, investments in foreign securities and foreign markets dominate (Russia (28.05\%), USA (27.99\%), Republic of Serbia (14.58\%), BRIC countries $(5.98 \%)$, Slovenia $(4.10 \%)$, other countries $(19.30 \%)$ ) (www.ilirika.rs),

- About $50 \%$ of the assets of the mutual fund Triumph was invested in foreign markets (www.ilirika.rs),

- In the structure of the portfolio of the mutual fund Raiffeisen Cash term deposits with banks dominate, with a participation of $67.27 \%$ (www.raiffeiseninvest.rs),

- Raiffeisen World's investment portfolio is dominated by investments in exchangetraded funds (ETFs) (58.99\%) (www.raiffeiseninvest.rs).

Despite the lack of statistical significance of the entire regression model in the case of the remaining five mutual funds, the presence of the statistical significance regarding the individual elements of the regression model ( $\alpha$ coefficient) was identified in the case of three out of the 
mentioned five funds. Also, it is encouraging that the fulfillment of the basic assumptions of the regression model (assumptions about the normality of the distribution, homoscedasticity and residual independence) is found in the case of the majority of the examined funds (Table 3 ).

The results of the Kolmogorov-Smirnov test show that in the case of seven out of eight analyzed mutual funds, the assumption about the normality of the distribution of the residuals is fulfilled, which supports the validity of the used linear regression model. The realized levels of significance of the test indicate that only in the case of the Triumph mutual fund, the zero hypothesis on the normality of the distribution of the residuals is rejected. The presence of significance implies the acceptance of an alternative hypothesis of the absence of normality of the distribution of the stochastic elements.

Durbin-Watson test was used to test the autocorrelation of residuals. The lower and upper bounds of the $d$ statistics for $d<2$ are $d_{1}=1.549$ and $d_{2}=1.616$. In the case of mutual funds Ilirika Cash Dinar and Raiffeisen Cash, calculated d statistics are lower than the lower limit, and therefore, the zero hypothesis of the lack of positive correlation is rejected and the alternative hypotheses is accepted. On the other hand, in the case of the mutual funds, Raiffeisen World and Kombank In Fund, the calculated $d$ statistics are higher than the upper limit, which implies that the zero hypothesis on the lack of positive correlation and independence of the residuals is accepted.

For the value of the $d$ statistics $d>2$, the lower and upper bounds $d_{1}$ and $d_{2}$ are replaced by $4-d_{2}$ and 4- $d_{1}$. In the case of all mutual funds with $d$ statistics greater than 2 (FIMA ProActive, Ilirika Dynamic, Triumph and Ilirika Balanced), the zero hypothesis on the absence of negative autocorrelation is accepted, because in the case of the listed funds $d$ statistics are lower than the lower limit 4- $d_{2}$ which is 2.384 .

Based on the above, it is concluded that in the case of six out of eight analyzed mutual funds, the assumption on the independence of the residuals is fulfilled, as an important assumption of the validity of the applied linear regression model.

The statistical validity of the regression model is confirmed also by the results of the Glejser test used to detect heteroscedasticity. Since the absence of significance $($ sig $>0.05)$ means acceptance of the zero hypothesis on the equality of the residual variance, it is concluded that in the case of all eight

Table 3. Checking the fulfillment of the basic assumptions of the regression model

\begin{tabular}{lccccc}
\hline \multirow{2}{*}{ Name of Fund } & \multicolumn{2}{c}{$\begin{array}{c}\text { Kolmogorov- } \\
\text { Smirnov test }\end{array}$} & $\begin{array}{c}\text { Durbin-Watson } \\
\text { test }\end{array}$ & \multicolumn{2}{c}{ Glejser test } \\
\cline { 2 - 6 } & Statistic & Sig. & $\boldsymbol{d}$ Statistics & $\boldsymbol{b}_{\boldsymbol{1}}$ & Sig. \\
\hline Ilirika Cash Dinar & 0.075 & 0.200 & 1.388 & 0.000 & 0.900 \\
Raiffeisen Cash & 0.074 & 0.200 & 1.375 & -0.002 & 0.294 \\
FIMA ProActive & 0.101 & 0.200 & 2.243 & 0.054 & 0.243 \\
Ilirika Dynamic & 0.081 & 0.200 & 2.111 & -0.007 & 0.907 \\
Triumph & $0.191^{*}$ & 0.000 & 2.334 & -0.109 & 0.491 \\
Raiffeisen World & 0.050 & 0.200 & 1.739 & -0.097 & 0.066 \\
Ilirika Balanced & 0.104 & 0.167 & 2.370 & -0.053 & 0.339 \\
Kombank In Fond & 0.103 & 0.181 & 1.979 & -0.031 & 0.471 \\
\hline * Statistically significant at a level of 0.05 & & & &
\end{tabular}


analyzed mutual funds there is no problem of heteroscedasticity. This suggests that the results of the Glejser test supported the common assumption of the linear regression model on the homoscedasticity.

In addition to the selection capabilities measured by the Jensen's index, it is equally important to assess the market timing abilities of the portfolio managers of mutual funds in the Republic of Serbia. The timing ability of portfolio managers was tested using the Treynor-Mazuy model, and the results are shown in the Table 4.

In the observed period, statistically significant positive value of the markettiming coefficient $\left(\gamma_{i}\right)$ was realized only by the mutual fund FIMA ProActive. Portfolio manager of this fund has shown a satisfactory ability to anticipate market fluctuations. On the other hand, statistically significant negative value of the markettiming coefficient was realized by the mutual fund Raiffeisen World, which indicates wrong market timing and wrong decision making on the structure of portfolios that are incompatible with the emerging market trends. In the case of the remaining analyzed mutual funds in the Republic of Serbia, the obtained value of the market-timing coefficient is not statistically significant, and the absence of statistical significance indicates the absence of market timing abilities.

Accordingly, the portfolio managers of most Serbian mutual funds lack the necessary skill of the market timing. They are not able to predict the direction of market fluctuations and adequately structure the portfolio. The results obtained correspond to the conclusions reached by Treynor and Mazuy (1966), Chang and Lewellen (1984), Abdel-Kader and Kuang (2007), Škrinjarić (2013) and Chen et al. (2013).

Based on the above, it is concluded that calculated values of market-timing coefficient confirm the validity of the hypothesis $1 \mathrm{~b}$ in the case of seven out of eight analyzed open-end mutual funds in the

Table 4. Estimation of the performance of the portfolio of open-end mutual funds in the Republic of Serbia in the period 2011-2015, based on the Treynor-Mazuy model

\begin{tabular}{|c|c|c|c|c|c|c|}
\hline Name of Fund & $\alpha_{i}$ & $\beta_{i}$ & $\gamma_{i}$ & $R^{2}$ & $F$ & Sig \\
\hline Ilirika Cash Dinar & $\begin{array}{c}0.001 \\
(6.517)^{*}\end{array}$ & $\begin{array}{c}0.002 \\
(0.884)\end{array}$ & $\begin{array}{c}0.023 \\
(0.620)\end{array}$ & 0.014 & 0.415 & 0.662 \\
\hline Raiffeisen Cash & $\begin{array}{c}0.002 \\
(10.890)^{*}\end{array}$ & $\begin{array}{c}-0.005 \\
(-1.589)\end{array}$ & $\begin{array}{c}-0.053 \\
(-1.008)\end{array}$ & 0.044 & 1.299 & 0.281 \\
\hline FIMA ProActive & $\begin{array}{c}-0.004 \\
(-1.117)\end{array}$ & $\begin{array}{c}0.573 \\
(7.723)^{*}\end{array}$ & $\begin{array}{c}1.999 \\
(1.743)^{* *}\end{array}$ & 0.532 & $32.447 *$ & 0.000 \\
\hline Ilirika Dynamic & $\begin{array}{c}-0.001 \\
(-0.229)\end{array}$ & $\begin{array}{c}0.212 \\
(1.943)^{* *}\end{array}$ & $\begin{array}{c}-2.579 \\
(-1.533)\end{array}$ & 0.171 & $5.893^{*}$ & 0.005 \\
\hline Triumph & $\begin{array}{c}-0.030 \\
(-2.723)^{*}\end{array}$ & $\begin{array}{c}0.188 \\
(0.812)\end{array}$ & $\begin{array}{c}3.554 \\
(0.991)\end{array}$ & 0.019 & 0.563 & 0.573 \\
\hline Raiffeisen World & $\begin{array}{c}0.005 \\
(1.080)\end{array}$ & $\begin{array}{c}0.046 \\
(0.473)\end{array}$ & $\begin{array}{c}-2.824 \\
(-1.873)^{* *}\end{array}$ & 0.095 & $3.001 * *$ & 0.058 \\
\hline Ilirika Balanced & $\begin{array}{c}-0.004 \\
(-0.846)\end{array}$ & $\begin{array}{c}0.087 \\
(0.996)\end{array}$ & $\begin{array}{c}0.555 \\
(0.412)\end{array}$ & 0.017 & 0.500 & 0.609 \\
\hline Kombank In Fond & $\begin{array}{c}-0.001 \\
(-0.318)\end{array}$ & $\begin{array}{c}0.409 \\
(5.396)^{*}\end{array}$ & $\begin{array}{c}-1.479 \\
(-1.262)\end{array}$ & 0.461 & $24.391 *$ & 0.000 \\
\hline
\end{tabular}


Republic of Serbia. The validity of hypothesis $2 \mathrm{~b}$ is confirmed only in the case of FIMA ProActive mutual fund whose market timing coefficient is positive and statistically significant.

In addition to calculated values of markettiming coefficient, Table 4 also contains values of alpha index as a measure of selection ability of portfolio managers of mutual funds. Alpha index values from the Treynor-Mazuy model only confirm previous conclusions on the selection ability of portfolio managers of Serbian mutual funds based on the value of the alpha index from the Jensen model (Table 2). Therefore, the alpha index values from Treynor-Mazuy model were not subjected to a more detailed analysis.

It is important to note that the applied Ftest points to the statistical significance of the entire regression model in the case of $50 \%$ of the tested mutual funds (Table 4), while the results of Kolmogorov-Smirnov, Durbin-Watson and Glejser tests confirm the fulfillment of the basic assumptions of the regression model for most of the analyzed mutual funds (Table 5).

The realized levels of significance of the Kolmogorov-Smirnov test show that in the case of six out of eight analyzed mutual funds, the assumption about the normality of the distribution of the residuals is fulfilled. Alternative assumption about the absence of the normality of the distribution of the residuals is adopted only in the case of mutual funds Triumph and Ilirika Balanced.

The statistical validity of the regression model, in terms of meeting the assumption on the independence of the residuals was tested using the Durbin-Watson test. The lower and upper bounds of the $d$ statistics for $d<2$ are $d_{1}=1.514$ and $d_{2}=1.652$. The realized values of $d$ statistics show that a zero hypothesis on the lack of positive correlation is rejected in the case of mutual funds Ilirika Cash Dinar and Raiffeisen Cash, while it is accepted in the case of the mutual fund Raiffeisen World.

For the value of the $d$ statistics $d>2$, the lower and upper bounds $d_{1}$ and $d_{2}$ are replaced with $4-d_{2}$ and $4-d_{1}$. In the case of mutual funds FIMA ProActive, Ilirika Dynamic and Kombank In Fund, a zero hypothesis that there is no negative correlation is accepted, since in the case of these funds, $d$ statistics are smaller than $4-d_{2}$, i.e. it is smaller than 2.348. In the case of the remaining two mutual funds with $d$ statistics greater than 2 (Triumph and Ilirika Balanced), the test is inconclusive. It has

Table 5. Checking the fulfillment of the basic assumptions of the regression model

\begin{tabular}{lccccccc}
\hline \multirow{2}{*}{ Name of Fund } & \multicolumn{2}{c}{$\begin{array}{c}\text { Kolmogorov- } \\
\text { Smirnov test }\end{array}$} & $\begin{array}{c}\text { Durbin- } \\
\text { Watson test }\end{array}$ & \multicolumn{4}{c}{ Glejser test } \\
\cline { 2 - 8 } & Statistic & Sig. & d Statistics & $\boldsymbol{b}_{\boldsymbol{1}}$ & Sig. & $\boldsymbol{b}_{\mathbf{2}}$ & Sig. \\
\hline Ilirika Cash Dinar & 0.070 & 0.200 & 1.365 & 0.000 & 0.829 & 0.006 & 0.786 \\
Raiffeisen Cash & 0.090 & 0.200 & 1.403 & 0.000 & 0.928 & 0.053 & 0.114 \\
FIMA ProActive & 0.097 & 0.200 & 2.278 & $0.123^{*}$ & 0.016 & 0.607 & 0.428 \\
Ilirika Dynamic & 0.055 & 0.200 & 2.118 & -0.010 & 0.877 & -0.385 & 0.707 \\
Triumph & $0.172^{*}$ & 0.000 & 2.368 & -0.265 & 0.124 & $-6.138^{*}$ & 0.023 \\
Raiffeisen World & 0.070 & 0.200 & 1.786 & -0.061 & 0.257 & 0.843 & 0.313 \\
Ilirika Balanced & $0.114^{* *}$ & 0.050 & 2.364 & -0.056 & 0.379 & 0.116 & 0.906 \\
Kombank In Fond & 0.089 & 0.200 & 2.034 & 0.018 & 0.702 & $1.819^{*}$ & 0.015 \\
\hline * Statistically significant at a level of 0.05 & & & & & & \\
** Statistically significant at a level of 0.10 & & & & & & &
\end{tabular}


been impossible to reach any conclusion on the presence or absence of autocorrelation of residuals, because $d$ statistics in the case of these funds is in the range from 4- $d_{2}$ to $4-d_{1}$.

Based on the Durbin-Watson test, it is concluded that in the case of four out of eight analyzed mutual funds, the assumption on the independence of stochastic elements is fulfilled. In the case of two funds, this assumption is not met, while in the case of the remaining two funds, the test is inconclusive.

Finally, the results of the Glejser test show that in the case of five out of eight examined funds there is no problem of heteroscedasticity, as evidenced by the absence of significance (sig $>0.05)$ which implies the acceptance of the zero hypothesis on the equality of the residual variance. The problem of heteroscedasticity occurs in the case of mutual funds FIMA ProActive, Triumph and Kombank In Fund.

\section{CONCLUSION}

In the Republic of Serbia, thus far, there have been no extensive empirical research on the mutual fund portfolio performance evaluation. In the financial literature of the country, descriptive studies examining the Serbian mutual fund industry can be found, however, there is no research on the performance of mutual funds. The unexploredness of this issue was a motive for the implementation of an adequate analysis of the Serbian mutual fund industry, based on the relevant foreign literature.

General conclusion of the research is that portfolio managers of most actively managed open-end mutual funds in the Republic of Serbia do not have selection ability and market timing ability and therefore fail to achieve better performance than the market. The justification for active management of portfolio of mutual funds is questioned as the performance achieved by the active portfolio management in most cases is not superior to the average market performance. The performance of funds would be even worse if managerial fees and transaction costs were included in the analysis. Mutual funds in the Republic of Serbia publish their returns on a gross basis, which is why managerial fees are not taken into account. Therefore, the proposal for future research is to include managerial fees in the analysis and establish the gross alpha, as well as the net alpha that more closely determines the costeffectiveness of investments in actively managed mutual funds.

One of the limitations of the research is reflected in the fact that the analysis does not cover all open-end mutual funds in the Republic of Serbia, but eight out of twelve, i.e. two thirds of the funds. The inclusion of more funds in the analysis would result in a shorter period of observation and research, since the remaining four open-end mutual funds were established during or after 2011, and the shortening of the research period would call into question the validity of the results obtained. Another important limitation relates precisely to the time dimension of data, i.e. the length of the analyzed period. Research period 2011-2015 is long enough to derive valid conclusions thanks to the use of monthly rates of return, but it is nevertheless significantly shorter than the periods covered by relevant studies in the United States and other developed countries. Considering the short history of the operations of mutual funds in the Republic of Serbia ${ }^{5}$ and the fact that many funds in the meanwhile have stopped working or have merged for the purpose of 
survival, it was not possible to cover a period longer than five years without reducing the number of mutual funds tested. Possible omission of half or most of the funds from the analysis would leave the question of their performance and performance of the mutual fund industry as a whole. This would definitely cause much uncertainties, while generalization would not be possible, because based on the performance of a small number of mutual funds it would not be possible to make reliable conclusions about industry's performance. It can be concluded that the beginning of the survey marked a trade off between the length of the analyzed period and the number of tested funds, and the optimal solution was found in the form of a five-year period and an analysis of two thirds of mutual funds.

Accordingly, the authors recommend that the research be repeated after a certain period of time, in the hope that the existing mutual funds will continue to operate, without taking over, merging or eventually terminating their work. The flow of time will enable overcoming the limits in terms of the time dimension of the data and, consequently, increase the reliability of survey results. Desired analysis would include a longer period of time with the existing or higher number of analyzed mutual funds.

Given the lack of statistical validity of the used regression models in terms of the particular mutual funds, there is a need to improve the results of the F-test in the future research. The proposal is, instead to use one benchmark, to include, as an alternative, several benchmark indices for each mutual fund and as the basic criterion when selecting a benchmark to use geographical exposure of the fund assets. In this way, the validity of used regression models and the reliability of obtained research results would

\footnotetext{
${ }^{5}$ The first mutual fund on the territory of the Republic of Serbia - Delta Plus fund has started to operate on March $9^{\text {th }}, 2007$.
}

be increased.

It should also be noted that the risk-free rate of return represented by the average monthly rate of return on the treasury bills of the National Bank of Serbia is relatively high since it reflects the overall riskiness of Serbian financial market, with all specific transition characteristics. Therefore, in order to examine the impact of the risk-free rate of return, the alpha index in future research can be calculated by including and excluding the risk-free rate of return from the analysis, and in view of the research carried out by Sajter (2011).

One should not lose sight of the suggestion made by certain authors (Goetzmann et al., 2000; Bollen \& Busse, 2001; Swinkels \& Tjong-A-Tjoe, 2007), which refers to the implementation of daily tests of the market timing ability of portfolio managers instead of the conducted monthly tests. Authors claim that daily tests indicate a greater ability of portfolio managers to predict market fluctuations because in reality the decisions are not made on a monthly basis, but on a daily basis.

The research can be improved by taking into account funds that ceased to exist in the meanwhile or have merged with other funds due to poor results. Their inclusion into the analysis would give a more realistic assessment of the performance of Serbian mutual funds and a more realistic assessment of capabilities of Serbian portfolio managers, because the exclusion of these funds from the analysis overestimates realized returns and underestimates the risks taken.

All planned studies aim to overcome the described limitations and improve the reliability and validity of the obtained assessments of the performance of the portfolio of open-end mutual funds in the Republic of Serbia. 


\section{Appendix}

Table 6. Logarithmic monthly rates of return of mutual fund portfolio $\left(r_{i, t}\right)$, monthly riskfree rate of return $\left(r_{f, t}\right)$ and monthly market rate of return $\left(r_{m, t}\right)$

\begin{tabular}{|c|c|c|c|c|c|c|c|c|c|c|}
\hline$m / y$ & $r_{i l, t}$ & $r_{i 2, t}$ & $r_{i 3, t}$ & $r_{i 4, t}$ & $r_{i 5, t}$ & $r_{i 6, t}$ & $r_{i 7, t}$ & $r_{i 8, t}$ & $r_{f, t}$ & $r_{m, t}$ \\
\hline $01 / 2011$ & 0.0095 & 0.0085 & 0.0419 & 0.0173 & 0.0092 & 0.0195 & -0.0036 & 0.0525 & 0.0093 & 0.0809 \\
\hline $02 / 2011$ & 0.0089 & 0095 & 222 & 0.0331 & & & -0.0088 & & 94 & 258 \\
\hline $03 / 2011$ & 0.0101 & 0.01 & 1 & -0.022 & & 0.019 & & & & \\
\hline $04 / 2011$ & 0.0095 & 0.01 & -0.0 & -0.0204 & & & & & & 17 \\
\hline & & & & & & & & & & 657 \\
\hline $06 / 2011$ & & & & & & .0231 & & & & -0.075 \\
\hline $07 / 2011$ & 0.009 & 0.009 & .022 & 0.006 & -0.0409 & .015 & 0067 & & 0093 & -0.048 \\
\hline $08 / 2011$ & 0.0111 & 0.0101 & -0.036 & -0.0838 & -0.0163 & -0.096 & & -0.0931 & 0.0093 & -0.096 \\
\hline 09/2011 & 0.0091 & 0.0101 & -0.021 & -0.0468 & 0.0484 & 0.0047 & -0.0097 & -0.034 & 0.009 & -0.104 \\
\hline $10 / 2011$ & 0.0093 & 0.0128 & $-1 \mathrm{E}-04$ & -0.0214 & 0.047 & 0.0494 & 0.0035 & 0.0312 & 0.0086 & -0.019 \\
\hline $11 / 2011$ & 0.0089 & 0.0129 & -0.019 & -0.0118 & -0.001 & 0.0006 & 0.0299 & -0.0874 & 0.0082 & -0.086 \\
\hline $12 / 2011$ & 0.009 & 0.0107 & 0.0439 & 0.0057 & 0.0147 & 0.0674 & 0.0047 & 0.0056 & 0.0078 & 0.0035 \\
\hline $01 / 2012$ & 0.009 & 0.0091 & -0.009 & -0.0124 & -0.0064 & 0.0377 & 0.0075 & 0.0135 & 0.0077 & -0.007 \\
\hline $02 / 2012$ & 0.0079 & 0.0081 & 0.0683 & 0.0101 & 0.0127 & 0.0532 & 0.0 & 0.0899 & 0.0076 & 0.0651 \\
\hline $03 / 2012$ & 0.008 & 0.0085 & 0.0083 & -0.0058 & -0.0089 & 0.0237 & 0.0 & -0.0422 & 0.0076 & -0.006 \\
\hline & 0.0085 & 0.0101 & & -0.0223 & & & & & 0.0076 & -0.055 \\
\hline $05 / 20$ & 0.0085 & & & & & & & & 0.0076 & -0.073 \\
\hline $06 / 20$ & 0.008 & & & & & & $-0 .($ & -0.0 & 0.0079 & -0.019 \\
\hline $07 / 20$ & 093 & & & & & & & & 0.0081 & 019 \\
\hline $08 / 20$ & .009 & & & -0.0 & -0.0 & & & 16 & 0.009 & 0.005 \\
\hline 09/2012 & 0.0082 & 0089 & & & -0.0 & -0.017 & -0.0 & 0.0159 & 0.0086 & -0.02 \\
\hline $10 / 2012$ & 0.0097 & 0114 & & -0.0392 & -0.0 & .031 & 12 & 18 & 0.0086 & 0.0327 \\
\hline $11 / 2012$ & 0088 & 0095 & 084 & 0.0073 & -0.0 & -0.008 & 0.0 & 031 & .0087 & .0333 \\
\hline $12 / 2012$ & 0091 & 0101 & 293 & -0.036 & -0.0 & 0.0227 & 0.0 & 0.0003 & 0.0079 & 0.0922 \\
\hline $01 / 2013$ & 0089 & 0104 & & & & & & & .0076 & 0.0577 \\
\hline & 008 & & .006 & & & & & -0.0 & .0075 & -0.008 \\
\hline & 0.0079 & & & & & & & & 0.0074 & 0.0271 \\
\hline & 0086 & & & & & & & & & 24 \\
\hline & & & & & & & & & & \\
\hline & & & & & & & & & 007 & \\
\hline $07 / 2$ & & & & & & & & & 0.0071 & 298 \\
\hline $08 / 2$ & & & & & & & & & 071 & 374 \\
\hline $09 / 2$ & & & & & & & & & 0.0073 & 125 \\
\hline & & & & & & & & & 0.0073 & 012 \\
\hline $11 / 20$ & 0.0066 & 0.0076 & & -0.0 & -0.1 & 039 & & & 0.0069 & 355 \\
\hline $12 / 2$ & & & & & & & & & 0.0064 & 0.0284 \\
\hline & & & & & & & & & 0.006 & 244 \\
\hline $02 / 2$ & & & & & & & & & 0.006 & -0.006 \\
\hline $03 / 20$ & 0.0074 & & & & -0.0 & -0.002 & & & 0.006 & -0.003 \\
\hline $04 / 20$ & & & & & -0.0807 & & & & 0.006 & 0.0295 \\
\hline $05 / 2014$ & 0.0061 & 0069 & & 0.0 & & 0.0348 & & 0.0136 & 0.0057 & 0.0069 \\
\hline $06 / 2014$ & 0.0067 & 0072 & 009 & -0.0347 & -0.1592 & 0.022 & -0.0 & 0.0029 & 0.0053 & -0.028 \\
\hline $07 / 2014$ & 0.0061 & 0067 & 287 & -0.0 & & 0.0139 & & 172 & 0.0051 & 0.0421 \\
\hline 08/2014 & 0.0056 & 0.0062 & & & & & & & 0.0052 & 0.0618 \\
\hline 09/2014 & 0.0063 & 0.0069 & & & -0.01 & 132 & & .0164 & 0.0052 & 487 \\
\hline $10 / 2014$ & 0.0061 & 0.0067 & & & -0.0 & & & & & 0.0492 \\
\hline & & & & & & & & & .0051 & 0.001 \\
\hline & & & & & & & & & 048 & -0.031 \\
\hline & & & & & & & & & & 0.0093 \\
\hline & & & & & & & & & & \\
\hline & & & & & & & & & & 299 \\
\hline & & & & & & & & & 339 & 0.0403 \\
\hline & & & & & & & & & 0.0037 & 0.011 \\
\hline & & & & & & & & & 0.0036 & -0.086 \\
\hline & & & & & 0.00 & 0.0019 & 0.01 & 0.0047 & 0.0033 & 0.016 \\
\hline & 0.0047 & 0.0056 & & -0.0906 & -0.0528 & -0.054 & -0.0502 & -0.0093 & 0.0031 & -0.025 \\
\hline & & 0.0046 & 0.0026 & -0.03 & -0.0 & -0.033 & & -0.0025 & 0.0027 & 0.0016 \\
\hline & 0.0037 & 0.0044 & & & & & & & 0.0022 & -0.011 \\
\hline & 0.0037 & & -0.011 & 0.0299 & 0.0109 & 0.0126 & & 0.0268 & 0.0021 & 0.0101 \\
\hline $12 / 2015$ & 0.0058 & 0.0036 & 0.0156 & -0.0503 & -0.0351 & -0.033 & -0.0231 & 0.008 & 0.0021 & 0.0467 \\
\hline
\end{tabular}




\title{
ОЦЕНА ПЕРФОРМАНСИ ПОРТФОЛИЈА ИНВЕСТИЦИОНИХ ФОНДОВА У РЕПУБЛИЦИ СРБИЈИ
}

\author{
Миљан Лековић, Милена Јакшић, Драгана Гњатовић
}

\section{Извод}

У раду се оцењују перформансе отворених инвестиционих фондова у Републици Србији остварене у периоду 2011-2015. године, применом разноврсних приступа моделирању заснованих на различитим моделима. Циљ рада је да се теоријско-методолошки и емпиријски сагледа оправданост активног управљања портфолиом инвестиционих фондова и испита присуство селекционе способности и способности тајминга тржишта српских портфолио менаџера. Резултати истраживања показују да активним управљањем портфолиом инвестиционих фондова у Републици Србији нису остварене боље перформансе од просечних тржишних перформанси. Портфолио менаџерима већине српских инвестиционих фондова недостају способност избора профитабилних хартија од вредности и способност тајминга тржишта.

Кључне речи: инвестициони фондови, портфолио, селекциона способност, способност тајминга тржишта

\section{References}

Abdel-Kader, M., \& Kuang, Y. (2007). Risk-Adjusted Performance, Selectivity, Timing Ability and Performance Persistence of Hong Kong Mutual Funds. Journal of AsiaPacific Business, 8 (2), 25-58.

Aragon, G.O., \& Ferson, W.E. (2006). Portfolio Performance Evaluation. Foundations and Trends in Finance, 2 (2), 83190.

Baker, M., Litov, L., Wachter, J.A., \& Wurgler, J. (2010). Can Mutual Fund Managers Pick Stocks? Evidence from Their Trades Prior to Earnings Announcements. Journal of Financial and Quantitative Analysis, 45 (5), 1111-1131.

Bialkowski, J., \& Otten, R. (2011). Emerging Market Mutual Fund Performance: Evidence for Poland. The North American Journal of Economics and Finance, 22 (2), 118-130.

Bogle, J. (1998). The Implications of Style
Analysis for Mutual Fund Performance Evaluation. The Journal of Portfolio Management, 24 (4), 34-42.

Bollen, N.P.B., \& Busse, J.A. (2001). On the Timing Ability of Mutual Fund Managers. The Journal of Finance, 56 (3), 1075-1094.

Carlson, R.S. (1970). Aggregate Performance of Mutual Funds, 1948-1967. Journal of Financial and Quantitative Analysis, 5 (1), 1-32.

Chang, E.C., \& Lewellen, W.G. (1984). Market Timing and Mutual Fund Investment Performance. The Journal of Business, 57 (1), 57-72.

Chang, E.C., \& Lewellen, W. G. (1985). An Arbitrage Pricing Approach to Evaluating Mutual Fund Performance. Journal of Financial Research, 8 (1), 15-30.

Chen, D., Gan, C., \& Hu, B. (2013). An Empirical Study of Mutual Funds Performance in China. Working Paper, No. 2, Faculty of Commerce. Retreived from https://researcharchive.lincoln.ac.nz/bitstrea 
m/handle/10182/5525/FoC_wp_02.pdf;jsessi onid=5BB6CED589D9379200792F2E0EB0

3D66? sequence $=1$

Chen, H.-L., Jegadeesh, N., \& Wermers, R. (2000). The Value of Active Mutual Fund Management: An Examination of the Stockholdings and Trades of Fund Managers. The Journal of Financial and Quantitative Analysis, 35 (3), 343-368.

Davis, J.L. (2001). Mutual Fund Performance and Manager Style. Financial Analysts Journal, 57 (1), 19-27.

Francis, J.C., \& Kim, D. (2013). Modern Portfolio Theory: Foundations, Analysis and New Developments. John Wiley \& Sons, Inc. Hoboken, New Jersey.

Friend, I., Brown, F.E., Herman, E.S., \& Vickers, D. (1962). A Study of Mutual Funds. U.S. Government Printing Office, Washington, D.C.

Glejser, H. (1969). A New Test for Heteroskedasticity. Journal of the American Statistical Association. 64 (325), 316-323.

Goetzmann, W.N., \& Ibbotson, R.G. (1994). Do Winners Repeat? The Journal of Portfolio Management, 20 (2), 9-18.

Goetzmann, W.N., Ingersoll, J., \& Ivković, Z. (2000). Monthly Measurement of Daily Timers. Journal of Financial and Quantitative Analysis, 35 (3), 257-290.

Grewe, O., \& Stehle, R. (2001). The LongRun Performance of German Stock Mutual Funds. EFMA 2001 Lugano Meetings. Retreived from https://ssrn.com/abstract=271452

Grinblatt, M., \& Titman, S. (1989). Mutual Fund Performance: An Analysis of Quarterly Portfolio Holdings. The Journal of Business, 62 (3), 393-416.

Harlow, W., \& Brown, K. (2006). The Right Answer to the Wrong Question: Identifying Superior Active Portfolio Management. Journal of Investment
Management, 4 (4), 15-40.

Henriksson, R.D. (1984). Market Timing and Mutual Fund Performance: An Empirical Investigation. The Journal of Business, 57 (1), 73-96.

Ilirika DZU Investment Fund Management Company, Retrieved from http://www.ilirika.rs/.

Ippolito, R. (1989). Efficiency with Costly Information: A Study of Mutual Fund Performance. Quarterly Journal of Economics, 104 (1), 1-23.

Jagrič, T., Podobnik, B., Strašek, S., \& Jagrič, V. (2007). Risk-adjusted Performance of Mutual Funds: Some Tests. South-Eastern Europe Journal of Economics, 5 (2), 233-244.

Jensen, M.C. (1968). The Performance of Mutual Funds in the Period 1945-1964. Journal of Finance, 23 (2), 389-416.

Jiang, G.J., Yao, T., \& Yu, T. (2007). Do Mutual Funds Time the Market? Evidence from Portfolio Holdings. Journal of Financial Economics, 86 (3), 724-758.

Kim, S.S., \& Sohn, P. (2013). Market Timing Performance in the Korean Fund Market: Evidence from Portfolio Holdings. Procedia Economics and Finance, 5, 443452.

Kon, S.J. (1983). The Market Timing Performance of Mutual Fund Managers. The Journal of Business, 56 (3), 323-347.

Kosowski, R., Timmermann, A., Wermers, R., \& White, H. (2006). Can Mutual Fund "Stars" Really Pick Stocks? New Evidence from a Bootstrap Analysis. The Journal of Finance, 61 (6), 2551-2595.

Lee, C.F., \& Rahman, S. (1991). New Evidence on Timing and Security Selection Skill of Mutual Fund Managers. The Journal of Portfolio Management, 17 (2), 80-83.

Mains, N.E. (1977). Risk, the Pricing of Capital Assets, and the Evaluation of Investment Portfolios: Comment. The Journal 
of Business, 50 (3), 371-384.

Malkiel, B.G. (1995). Returns from Investing in Equity Mutual Funds: 1971 to 1991. Journal of Finance, 50 (2), 549-572.

Markovič-Hribernik, T., \& Vek, U. (2013). Do Mutual Fund Performance and the Abilities of Fund Managers in Slovenia Deviate from those in Developed Markets? Romanian Economic and Business Review, 8 (1), 130-139.

McDonald, J.G. (1974). Objectives and Performance of Mutual Funds, 1960-1969. Journal of Financial and Quantitative Analysis, 9 (3), 311-333.

Modigliani, F., \& Modigliani, L. (1997). Risk-Adjusted Performance. Journal of Portfolio Management, 23 (2), 45-54.

Otten, R., \& Bams, D. (2002). European Mutual Fund Performance. European Financial Management, 8 (1), 75-101.

Otten, R., \& Schweitzer, M. (2002). A Comparison Between the European and the U.S. Mutual Fund Industry. Managerial Finance, 28 (1), 14-35.

Pantić, N., \& Milojević, I. (2019). Investments and employment in tourism in the Republic of Serbia. Menadžment $u$ hotelijerstvu i turizmu - Hotel and Tourism Management, 7 (1), 95-104.

Podobnik, B., Balen, V., Jagric, T., \& Kolanovic, M. (2007) Croatian and Slovenian Mutual Funds and Bosnian Investments Funds. Czech Journal of Economics and Finance, 57 (3-4), 159-177.

Raiffeisen Invest, Investment Fund Management Company, Retrieved from https://www.raiffeiseninvest.rs/invest.155.ht $\mathrm{ml}$.

Redman, L.A., Gullet, N.S., \& Manakyan, H. (2000). The Performance of Global and International Mutual Funds. Journal of Financial and Strategic Decisions, 13 (1), 7585.
Sajter, D. (2011). Can Croatian Fund Managers Create Alpha Returns? Performance of Some Mutual Funds in Croatia. Ekonomski pregled, 62 (5-6), 248266.

Sharpe, W. F. (1966). Mutual Fund Performance. Journal of Business, 39 (1), 119-138.

Soldić Aleksić, J. (2011). Applied data analysis (in Serbian). Ekonomski fakultet $\mathrm{u}$ Beogradu. Beograd, Republika Srbija.

Swinkels, L., \& Rzezniczak, P. (2009). Performance Evaluation of Polish Mutual Fund Managers. International Journal of Emerging Markets, 4 (1), 26-42.

Swinkels, L., \& Tjong-A-Tjoe, L. (2007). Can Mutual Funds Time Investment Styles? Journal of Asset Management, 8 (2), 123132.

Škrinjarić, T. (2013). Market Timing Ability of Mutual Funds with Tests Applied on Several Croatian Funds. Croatian Operational Research Review, 4 (1), 176-186.

Treynor J.L. (1965). How to Rate Management of Investment Funds. Harvard Business Review, 43, 63-75.

Treynor, J.L., \& Black, F. (1973). How to Use Security Analysis to Improve Portfolio Selection. The Journal of Business, 46(1), 6686.

Treynor, J.L., \& Mazuy, K.K. (1966). Can Mutual Funds Outguess the Market? Harvard Business Review, 44, 131-136.

Veselinović, P., Dimitrijević, M., \& Kostić, M. (2019). Significance of Fiscal Policy for Economic Development and Agriculture. Economics of Agriculture, 66 (2), 357-373.

Wermers, R. (2000). Mutual Fund Performance: An Empirical Decomposition into Stock-Picking Talent, Style, Transactions Costs, and Expenses. The Journal of Finance, 55 (4), 1655-1695. 